\title{
Direct Growth of Flower-Shaped ZnO Nanostructures on FTO Substrate for Dye-Sensitized Solar Cells
}

\author{
Ahmad Umar 1,2, , Mohammad Shaheer Akhtar ${ }^{3}$, Tubia Almas 1,2,4, \\ Ahmed Abdulbaqi Ibrahim 1,2, Mohammed Sultan Al-Assiri ${ }^{2,5}$, Yoshitake Masuda ${ }^{6}$, \\ Qazi Inamur Rahman ${ }^{7}$ and Sotirios Baskoutas ${ }^{4}$ (D) \\ 1 Department of Chemistry, Faculty of Science and Arts, Najran University, Najran 11001, Saudi Arabia \\ 2 Promising Centre for Sensors and Electronic Devices (PCSED), Najran University, Najran 11001, Saudi Arabia \\ 3 New and Renewable Energy Material Development Center (NewREC), Chonbuk National University, \\ Chonbuk, 54896, Korea \\ 4 Department of Materials Science, University of Patras, 26504 Patras GR, Greece \\ 5 Department of Physics, Faculty of Science and Arts, Najran University, Najran 11001, Saudi Arabia \\ 6 National Institute of Advanced Industrial Science and Technology (AIST), 2266-98 Anagahora, \\ Shimoshidami, Moriyama-ku, Nagoya 463-8560, Japan \\ 7 Department of Chemistry, Integral University, Lucknow, Uttar Pradesh 226026, India \\ * Correspondence: ahmadumar786@gmail.com
}

Received: 27 May 2019; Accepted: 25 July 2019; Published: 4 August 2019

\begin{abstract}
The proposed work reports that $\mathrm{ZnO}$ nanoflowers were grown on fluorine-doped tin oxide (FTO) substrates via a solution process at low temperature. The high purity and well-crystalline behavior of $\mathrm{ZnO}$ nanoflowers were established by $\mathrm{X}$-ray diffraction. The morphological characteristics of $\mathrm{ZnO}$ nanoflowers were clearly revealed that the grown flower structures were in high density with 3D floral structure comprising of small rods assembled as petals. Using UV absorption and Raman spectroscopy, the optical and structural properties of the $\mathrm{ZnO}$ nanoflowers were studied. The photoelectrochemical properties of the $\mathrm{ZnO}$ nanoflowers were studied by utilizing as a photoanode for the manufacture of dye-sensitized solar cells (DSSCs). The fabricated DSSC with ZnO nanoflowers photoanode attained reasonable overall conversion efficiency of $\sim 1.40 \%$ and a short-circuit current density ( $\mathrm{J}_{\mathrm{SC}}$ ) of $\sim 4.22 \mathrm{~mA} \mathrm{~cm}{ }^{-2}$ with an open circuit voltage $\left(\mathrm{V}_{\mathrm{OC}}\right)$ of $0.615 \mathrm{~V}$ and a fill factor (FF) of $\sim 0.54$. $\mathrm{ZnO}$ nanostructures have given rise to possible utilization as an inexpensive and efficient photoanode materials for DSSCs.
\end{abstract}

Keywords: Flower-shaped ZnO structures; FTO substrate; Dye-sensitized solar cells: Photovoltaics

\section{Introduction}

People need to step up efforts to find highly efficient and renewable energy sources to maintain social and economic development [1-5]. A reliable and renewable energy source, solar energy is accounted as a future energy resource due to its abundance and completely free of cost from sunlight. A low-cost wide band gap semiconducting oxide based solar cell, named dye sensitized solar cell (DSSC) is considered as potential alternative in the field of photovoltaic devices due to its high power conversion efficiency (PCE) and ease of manufacturing [6-9]. Till now, Gratzel group reported so far highest PCE of $12.3 \%$ using DSSCs with nanoporous $\mathrm{TiO}_{2}$ photoanode [10]. Other than $\mathrm{TiO}_{2}$ photoanode, zinc oxide $(\mathrm{ZnO})$ nanomaterials are shown a great potential as an excellent wide-bandgap oxide semiconductor for photoanode in DSSCs because $\mathrm{ZnO}$ presents the similar band position and electron affinities along with high electron diffusivity and high electron mobility of 115 to $155 \mathrm{~cm}^{2} \mathrm{~V}^{-1} \mathrm{~s}^{-1}$, in comparison with $\mathrm{TiO}_{2}$ [11-14]. Importantly, these special properties of $\mathrm{ZnO}$ are reflected to help in reduction 
of recombination rate and efficient electron transport in the photoanode [15]. Most the reported DSSCs based on $\mathrm{ZnO}$ photoanodes are inferior to DSSCs based on the $\mathrm{TiO}_{2}$ photoanode [16-18], which normally can be attributed to $\mathrm{ZnO}$ dissolution to $\mathrm{Zn}^{2+}$ via the adsorbed acidic dye such as N3, N719, and black dye, resulting in the aggregate formation of $\mathrm{Zn}^{2+}$ and dye molecules [19]. These aggregates formation of $\mathrm{Zn}^{2+}$ /dye complexes are further blocked the injected electrons from the photoexcited dye molecules to the $\mathrm{ZnO}$, which results in decrease in proper electron injection. It is realized that some extent of research on the improvement in performance of ZnO-based DSSC are needed to outperform the aggregates formation of $\mathrm{Zn}^{2+} /$ dye complexes [19].

$\mathrm{ZnO}$ is highly scrutinized n-type semiconducting oxide owing to its an unique wide band gap of $3.37 \mathrm{eV}$ and considerable large exciton binding energy of $\sim 60 \mathrm{meV}$ at ambient condition [20,21]. The unique properties of $\mathrm{ZnO}$ materials have attracted attention in the area of electrochemical and photoelectrochemical devices because they have special ability to grow a variety of different nanostructures [22-29]. Apart from thermal growth of $\mathrm{ZnO}, \mathrm{ZnO}$ synthesis at low temperature solution processes has recently been popularized due to ease of processibility, high aspect growth ratio, low-cost, and high yield [30]. In past few years, researches are experimented to elevate the conversion efficiency of ZnO-based DSSCs by adopting different structural and morphological aspects like 1D, 2D, and $3 \mathrm{D}$ branched networks and mixed morphologies for preparing $\mathrm{ZnO}$ photoanodes [31-33]. Several works on the utilization of 1D and 2D ZnO-based photoanodes have already been reported, but the conversion efficiencies of DSSCs are not competent to $\mathrm{TiO}_{2}$ based DSSCs [29-33].

Herein, we report the low-temperature hydrothermal synthesis, characterization, and dye-sensitized solar cell (DSSC) application of $\mathrm{ZnO}$ nanoflowers. The $\mathrm{ZnO}$ nanoflowers were grown directly on the fluorine-doped tin oxide (FTO) substrate via simple hydrothermal process and directly used as working electrode for the dye absorption in DSSCs. The manufactured DSSC poses reasonable PCE of $\sim 1.40 \%$ along with open circuit voltage $\left(\mathrm{V}_{\mathrm{OC}}\right)$ of $0.615 \mathrm{~V}$, short-circuit current density (JSC) of $\sim 4.22 \mathrm{~mA} \mathrm{~cm}^{-2}$, and a fill factor (FF) of $\sim 0.54$.

\section{Materials and Methods}

\subsection{Synthesis of Flower-Shaped ZnO Nanostructures Directly Grown on FTO Substrate}

For the growth of flower-shaped $\mathrm{ZnO}$ nanostructures directly on the FTO substrate, a facile hydrothermal process was adopted. Briefly, $0.05 \mathrm{M}(1.2 \mathrm{~g})$ zinc nitrate hexahydrate $\left(\mathrm{Zn}\left(\mathrm{NO}_{3}\right)_{2} \cdot 6 \mathrm{H}_{2} \mathrm{O}\right)$, Sigma-Aldrich, Missouri, United States) solution was mixed in $50.0 \mathrm{ml}$ deionized (DI) water and stirred continuously at ambient temperature. Simultaneously, $0.05 \mathrm{M}(0.5 \mathrm{~g})$ aqueous solution of hexamethylenetetramine (HMTA, Sigma-Aldrich, Missouri, United States) was added in the stirred solution. A small portion (0.12 g) of poly(ethylene glycol) (PEG, MW: 20000, Sigma-Aldrich, Missouri, United States) was also introduced to reaction mixture under vigorous stirring at $25^{\circ} \mathrm{C}$ as a binder. The $\mathrm{pH}=8.0$ was maintained by adding few drops of liquid ammonia solution. Finally, cleaned FTO substrates were horizontally placed in the Teflon beaker and the resulting mixture was poured in it [7]. The Teflon beaker was placed in the stainless steel autoclave which was heated to $150^{\circ} \mathrm{C}$ for $8 \mathrm{~h}$. After completion of the reaction, the $\mathrm{ZnO}$ coated FTO substrates were removed from the autoclave and rinsed with ethanol and DI water and dried at room temperature. Finally, the substrate was heated at $250{ }^{\circ} \mathrm{C}$ for $1 \mathrm{~h}$ under air condition. It was presumed that the formation of the flower-shaped morphologies on the FTO substrate follows the below mentioned chemical reactions.

$$
\begin{gathered}
\left(\mathrm{CH}_{2}\right)_{6} \mathrm{~N}_{4}+6 \mathrm{H}_{2} \mathrm{O} \rightarrow 6 \mathrm{HCHO}+4 \mathrm{NH}_{3} \\
\mathrm{NH}_{3}+\mathrm{H}_{2} \mathrm{O} \leftrightarrow \mathrm{NH}^{4+}+\mathrm{OH}^{-} \\
\mathrm{Zn}^{2+}+2 \mathrm{OH}^{-} \rightarrow \mathrm{Zn}(\mathrm{OH})_{2} \\
\mathrm{Zn}(\mathrm{OH})_{2} \rightarrow \mathrm{ZnO}+\mathrm{H}_{2} \mathrm{O}
\end{gathered}
$$


Thus, $\mathrm{ZnO}$ nuclei were formed which after prolonged heating and reaction time, the formed $\mathrm{ZnO}$ nuclei were collectively assembled into the flower shaped $\mathrm{ZnO}$ nanostructures on the FTO substrate.

\subsection{Characterizations of Flower-Shaped ZnO Nanostructures Directly Grown on FTO Substrate}

Flower-shaped $\mathrm{ZnO}$ nanostructures directly grown on FTO substrate were examined by various techniques to inspect various characteristics and properties. The crystal structure and related characteristics were inspected by X-ray diffraction (XRD; PAN analytical Xpert Pro., Malvern Panalytical, Malvern, $\mathrm{UK})$ using $\mathrm{Cu}-\mathrm{K} \alpha$ radiation $\left(\lambda=1.54178 \AA\right.$ ) in the range of $20-70^{\circ}$. The field emission scanning electron microscopy (FESEM; JEOL-JSM-7600F, Akishima, Tokyo, Japan) was employed to monitor the morphological information of the prepared material. The qualitative localized chemical analysis and chemical compositions were inspected using energy-dispersive spectroscopy (EDS) attached with FESEM. The scattering characteristics have been investigated by Raman scattering spectroscopy (Perkin Elmer-Raman Station 400, Waltham, MA, USA) at room temperature. The X-ray Photoelectron Spectroscopy (XPS) (XPS, Kratos analytical, ESCA-3400, Shimazu, Kyoto, Kyoto Prefecture, Japan) measurements were conducted to determine the chemical composition and the elemental states in the prepared flower-shaped $\mathrm{ZnO}$ nanostructures by determining the binding energies. The applied X-ray source $(\mathrm{MgK} \alpha, 1253.6 \mathrm{eV})$ was operated at $10 \mathrm{kV}$ and $20 \mathrm{~mA}$. The specific Brunauer-Emmett-Teller (BET) surface area of flower-shaped $\mathrm{ZnO}$ nanostructures was evaluated by measuring Nitrogen adsorption via a Micromeritics ASAP 2020 nitrogen adsorption apparatus (Norcross, GA, USA).

\subsection{Fabrication of ZnO Nanoparticles-Based Flower-Shaped ZnO Nanostructures Directly Grown on FTO Substrate}

The DSSC based on flower-shaped ZnO nanostructures directly grown on FTO substrate was fabricated as reported earlier [7]. The flower-shaped $\mathrm{ZnO}$ nanostructures on FTO substrate was immersed into freshly prepared $0.3 \mathrm{M}$ ethanolic solution of cis-bis (isothiocyanate) bis (2,2-bipyridyl-4,4-dicarboxylate)-ruthenium(II) bistetrabutyl ammonium dye (N719) for $12 \mathrm{~h}$ under dark condition at $298 \mathrm{~K}$. Simultaneously, a counter electrode of Pt metal (thickness $=120 \mathrm{~nm}$ ) was made by the sputtering onto the FTO substrate. To manufacture the DSSC, the dye-absorbed ZnO-based electrode was attached with Pt counter electrode and edges were sealed using a $60-\mu \mathrm{m}$-thick polyimide sealing sheet. Consequently, the introduction of the liquid electrolyte comprising of $0.5 \mathrm{M} \mathrm{LiI}, 0.05 \mathrm{mM}$ $\mathrm{I}_{2}$, and $0.2 \mathrm{M}$ tert-butyl pyridine in acetonitrile was filled into cell via drilled small holes in the counter electrode. The active area of the fabricated DSSC was $0.5 \mathrm{~cm} \times 0.5 \mathrm{~cm}$. For the photocurrent density-voltage $(J-V)$ curve of the manufactured DSSC, a self-designed computerized digital multimeter coupled with ammeter and voltammeter was used under 1 sun light using the $1000 \mathrm{~W}$ metal halide lamp as light source. The intensity of light was adjusted and calibrated by Si reference solar cell to set the light intensity around one-sun $\left(100 \mathrm{~mW} / \mathrm{cm}^{2}\right)$ at $1.5 \mathrm{AM}$. The electrochemical behavior of fabricated DSSCs was analyzed by the electrochemical impedance (EIS) measurements using VersaSTAT4 potentiostat/galvanostat. EIS plot for fabricated DSSCs was measured by applying $10 \mathrm{mV}$ ac signal over the frequency range of $100 \mathrm{kHz}$ to $1 \mathrm{~Hz}$.

\section{Results and Discussion}

\subsection{Characterization and Properties of Flower-Shaped $\mathrm{ZnO}$ Nanostructures Directly Grown on FTO Substrate}

The XRD results of the synthesized $\mathrm{ZnO}$ nanostructures on FTO substrate are illustrated in Figure 1. From the XRD patterns, all characteristic diffraction peaks, such as (100), (002), (101), (102), (110), (103), (112), and (201), are well matched with JCPDS card no. 36-1451, deducing the hexagonal wurtzite structure of $\mathrm{ZnO}$ in synthesized $\mathrm{ZnO}$ nanostructures. Other diffraction peaks in Figure 1 are related to the FTO substrate. Moreover, the highest peak intensity at (001) for $\mathrm{ZnO}$ nanoflowers on the FTO substrate clearly evident that the $\mathrm{ZnO}$ nanoflowers grow perpendicular to the FTO substrate 
surface [34-36]. Besides, no other impurity-the related peak is detected from the observed XRD pattern, which revealed the wurtzite hexagonal phase of the grown nanoflowers.

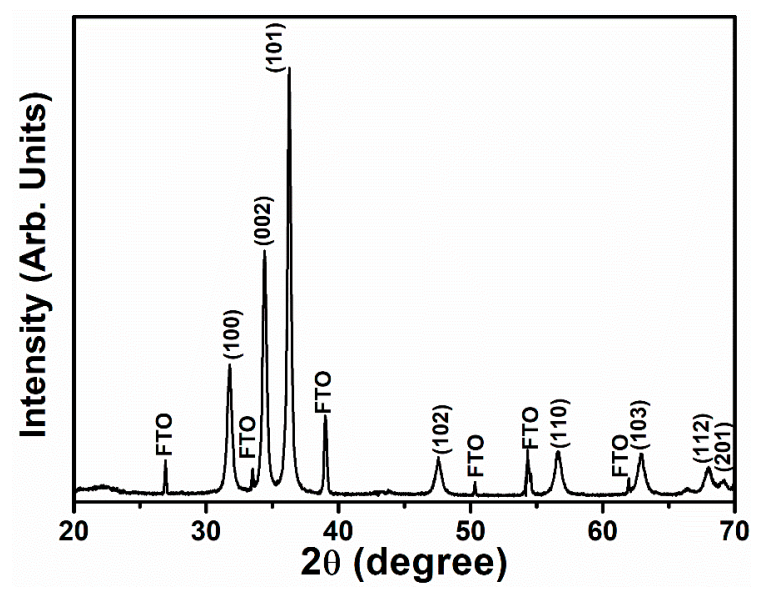

Figure 1. Typical XRD pattern of flower-shaped $\mathrm{ZnO}$ nanostructures directly grown on fluorine-doped tin oxide (FTO) substrate.

As shown in Figure 2a-d, the field-emission scanning electron microscopic (FESEM) images are used to explore the structure and morphology of the flower-shaped $\mathrm{ZnO}$ nanostructures. It is easy to see the well-grown flower-like morphology, which is comprised of small nanorods with a central peripheral rod. Figure 2c,d shows the high-resolution FESEM images of the $\mathrm{ZnO}$ nanostructures, which reveal that each petals are composed of agglomerated nanorods. Fascinatingly, some of the small nanorods are assembled in such a way that they are collectively formed the flower-shaped morphologies while most of the nanoflowers are grown almost perpendicularly on the surface of the substrate. These flower like morphologies are uniformly deposited on the whole substrate surface.
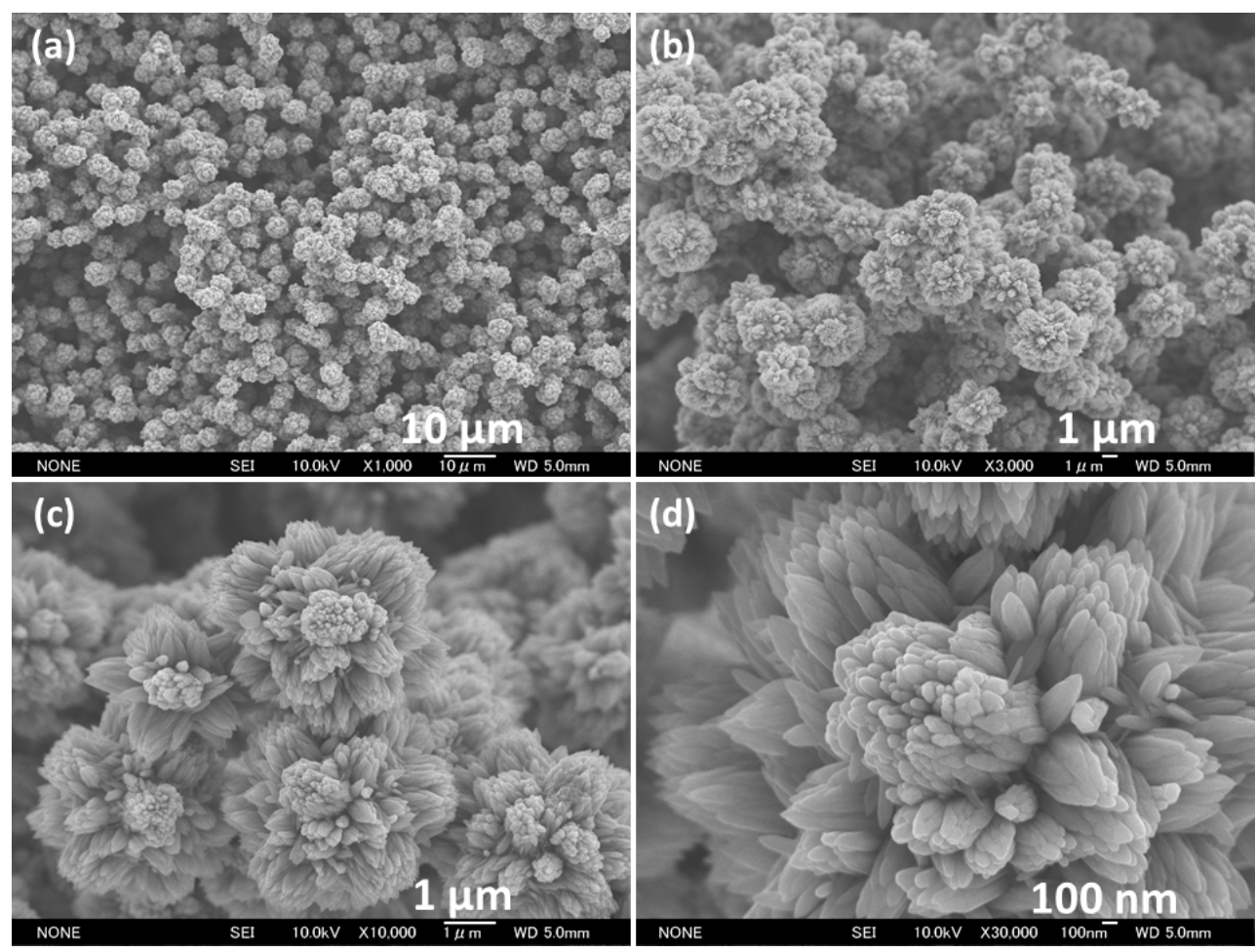

Figure 2. Typical field-emission scanning electron microscopy (FESEM) images (a-d) of flower-shaped $\mathrm{ZnO}$ nanostructures directly grown on FTO substrate. 
Using room temperature photoluminescence (PL) spectroscopy, the optical properties of the flower-shaped $\mathrm{ZnO}$ nanostructures were determined, as shown in Figure 3. Before each measurement, FTO/glass was used to remove the effects of fluorine tin oxide and glass $[37,38]$ as a reference. From Figure 3, the $\mathrm{ZnO}$ nanoflowers exhibits the strong emission peak at a lower wavelength along with a broad green emission at higher wavelength [39]. The $\mathrm{ZnO}$ nanoflowers show well-defined peak in the UV region, assigning the near-band-edge (NBE) emission of $\mathrm{ZnO}$ which normally appeared from the recombination process of free-exciton $[40,41]$. The broad green emissions are accounted from several intrinsic structural and surface defects such as interstitials oxygen defects $\left(\mathrm{O}_{\mathrm{i}}\right)$, oxygen vacancies $\left(\mathrm{V}_{\mathrm{O}}\right)$, and antisite oxygen $\left(\mathrm{O}_{\mathrm{Zn}}\right)$ in the synthesized $\mathrm{ZnO}$ nanoflowers [42]. It was suggested that the emission peaks are governed the electronic transitions due to the travelling of electron from valence band to the conduction band of the $\mathrm{ZnO}$ nanostructures [43].

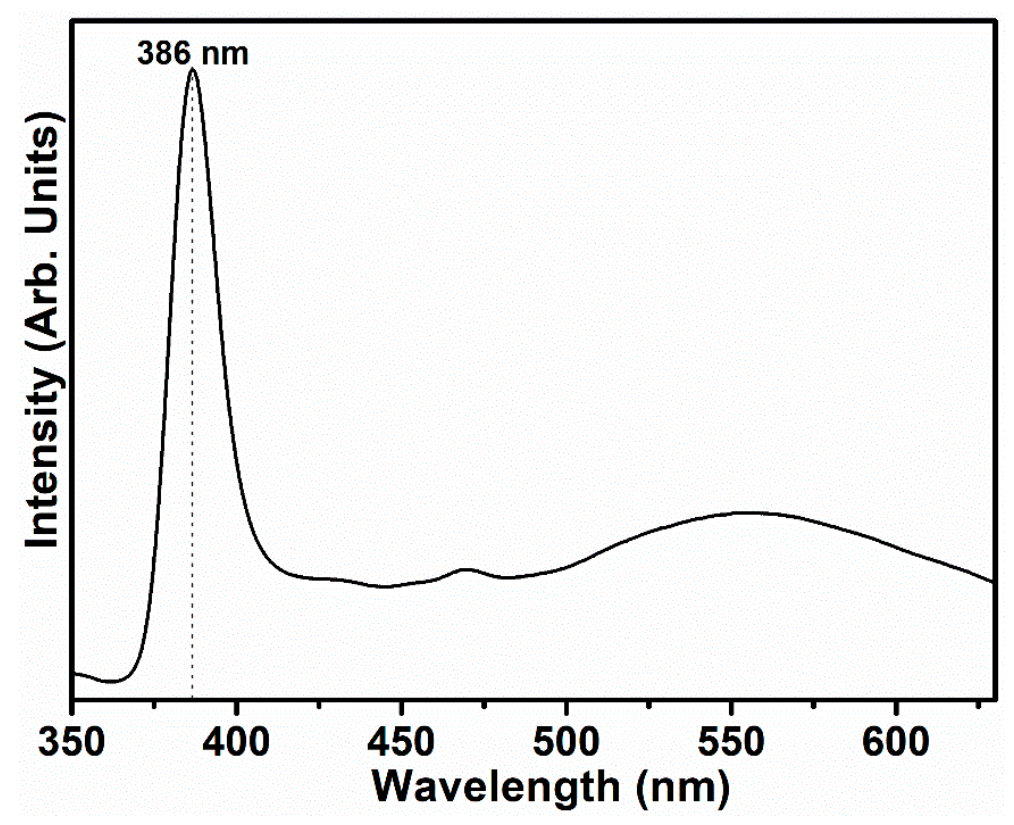

Figure 3. Room temperature PL spectrum of flower-shaped $\mathrm{ZnO}$ nanostructures directly grown on FTO substrate.

Raman scattering spectroscopy was determined to analyze the vibration modes and quality of the flower-shaped $\mathrm{ZnO}$ nanostructures, as shown in Figure 4. The intense Raman peak observed at $437.6 \mathrm{~cm}^{-1}$ due to metal-oxygen atom vibration, which is ascribed to $\mathrm{E}_{2}$ (high) mode. The appeared $\mathrm{E}_{2}$ (high) mode supports the usual formation of hexagonal $\mathrm{ZnO}$ nanostructures [44]. The second order Raman peak centered at $581.8 \mathrm{~cm}^{-1}$ is related to $\mathrm{E}_{1}(\mathrm{LO})$ mode $[45,46]$ which usually originated due to the presence of interstitials defects such as oxygen vacancies in zinc lattices. Two less intense Raman peaks centered at $335 \mathrm{~cm}^{-1}$ and $381 \mathrm{~cm}^{-1}$ are referred to $E_{2}($ high $)-E_{2}(l o w)$ mode or the origin of the multiple phonon scattering processes. The intense $\mathrm{E}_{2}$ (high) mode deduces the good crystal quality and structures of flower-shaped $\mathrm{ZnO}$ nanostructures grown on FTO substrate, which is well aligned with XRD outcomes. 


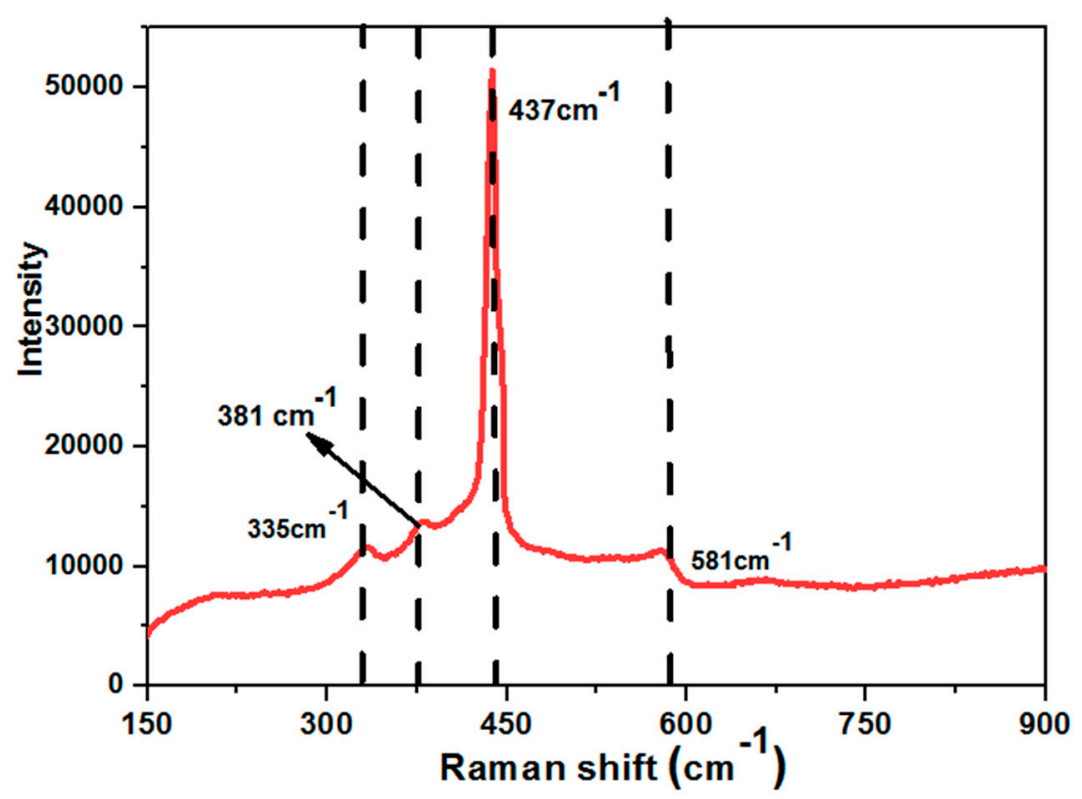

Figure 4. Typical Raman scattering spectrum of flower-shaped $\mathrm{ZnO}$ nanostructures directly grown on FTO substrate.

In addition, XPS measurement was evaluated for the synthesized flower-shaped $\mathrm{ZnO}$ nanostructures to elucidate the existence of surface species, composition, oxidation state, and electronic environment. The survey XPS (Figure 5a) spectrum displays that the synthesized $\mathrm{ZnO}$ nanoflowers recorded well-defined binding energies of $\mathrm{Zn} 2 \mathrm{p}, \mathrm{O} 1 \mathrm{~s}$, and small $\mathrm{C} 1 \mathrm{~s}$. The main reason for the existence of $\mathrm{C} 1 \mathrm{~s}$ at $284 \mathrm{eV}$ might be happened due to small amount of carbon species from hydrocarbons in precursors and solvents. From Figure 5b, the high-resolution Zn 2p XPS for the synthesized ZnO nanostructures shows binary binding energies at 1044.8 and $1021.7 \mathrm{eV}$, which are assigned to $\mathrm{Zn}$ $2 \mathrm{p}^{1 / 2}$ and $\mathrm{Zn} 2 \mathrm{p}^{3 / 2}$ spin-orbital splitting photoelectrons, respectively. Notably, the difference of $\mathrm{Zn} 2 \mathrm{p}$ binding energies is estimated to $23.1 \mathrm{eV}$ which is evidenced for $\mathrm{Zn}^{2+}$ oxidation state in $\mathrm{ZnO}$. From the high-resolution $\mathrm{O} 1 \mathrm{~s}$ XPS spectra (Figure $5 \mathrm{c}$ ), the binding energy at $530.8 \mathrm{eV}$ is ascribed to the lattice $\mathrm{Zn}-\mathrm{O}$ bond within the $\mathrm{ZnO}$ crystal. However, the two resolved binding energies at 530.3 and $532.7 \mathrm{eV}$ arise from the surface oxygen over the $\mathrm{ZnO}$ surfaces, which usually come from the atmospheric humidity and oxygen deficiencies/vacancies. The obtained $\mathrm{Zn} 2 \mathrm{p}$ and $\mathrm{O}$ 1s binding energies again confirm the high quality $\mathrm{ZnO}$ crystals with less impurities. 

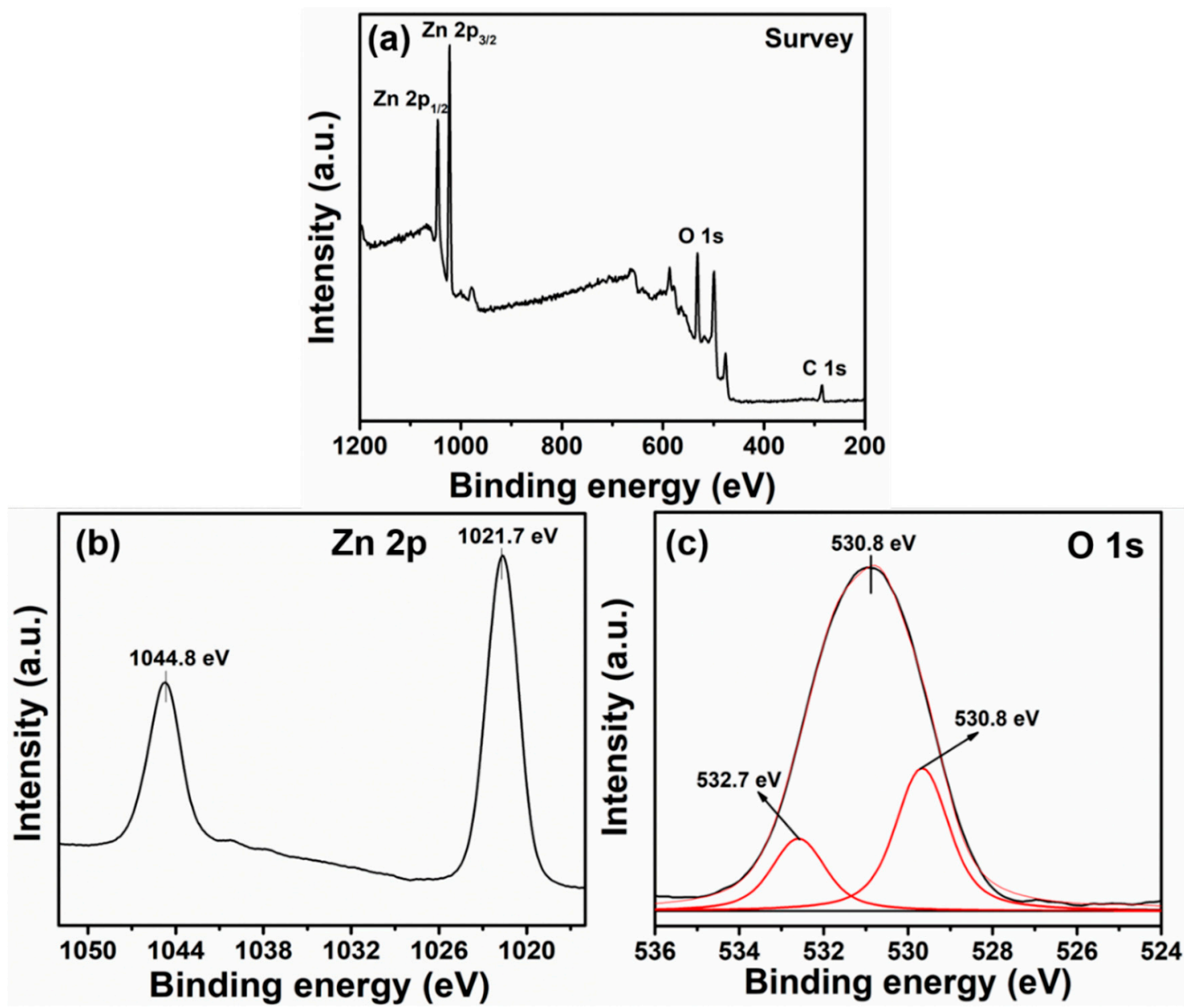

Figure 5. Typical XPS (a) full survey, (b) Zn 2p, and (c) O1s spectrum of flower-shaped ZnO nanostructures directly grown on FTO substrate.

\subsection{Dye-Sensitized Solar Cell Application of Flower-Shaped $\mathrm{ZnO}$ Nanostructures}

To define the photoelectrochemical properties of flower-shaped $\mathrm{ZnO}$ nanostructures, a DSSC has been manufactured and tested under 1 sun (AM1.5G, $100 \mathrm{~mW} / \mathrm{cm}^{2}$ ) to assess the photovoltaic properties of the synthesized flower-shaped $\mathrm{ZnO}$ nanostructures based photoanode. Figure 6a shows the J-V curve of the manufactured DSSC with the synthesized flower-shaped $\mathrm{ZnO}$ nanostructures based photoanode. The manufactured DSSC attained the healthy overall conversion efficiency of $\sim 1.40 \%$ along with open circuit voltage $\left(\mathrm{V}_{\mathrm{OC}}\right)$ of $0.615 \mathrm{~V}$, short-circuit current density $\left(\mathrm{J}_{\mathrm{SC}}\right)$ of $\sim 4.22 \mathrm{~mA}$ $\mathrm{cm}^{-2}$, and a fill factor (FF) of $\sim 0.54$. Relatively good $\mathrm{V}_{\mathrm{OC}}$ and FF in DSSC might be accounted from the creation of large grain sizes in the $\mathrm{ZnO}$ nanostructures which result in the interface recombination rate at the interface of the $\mathrm{ZnO}$ nanostructures/electrolyte. 

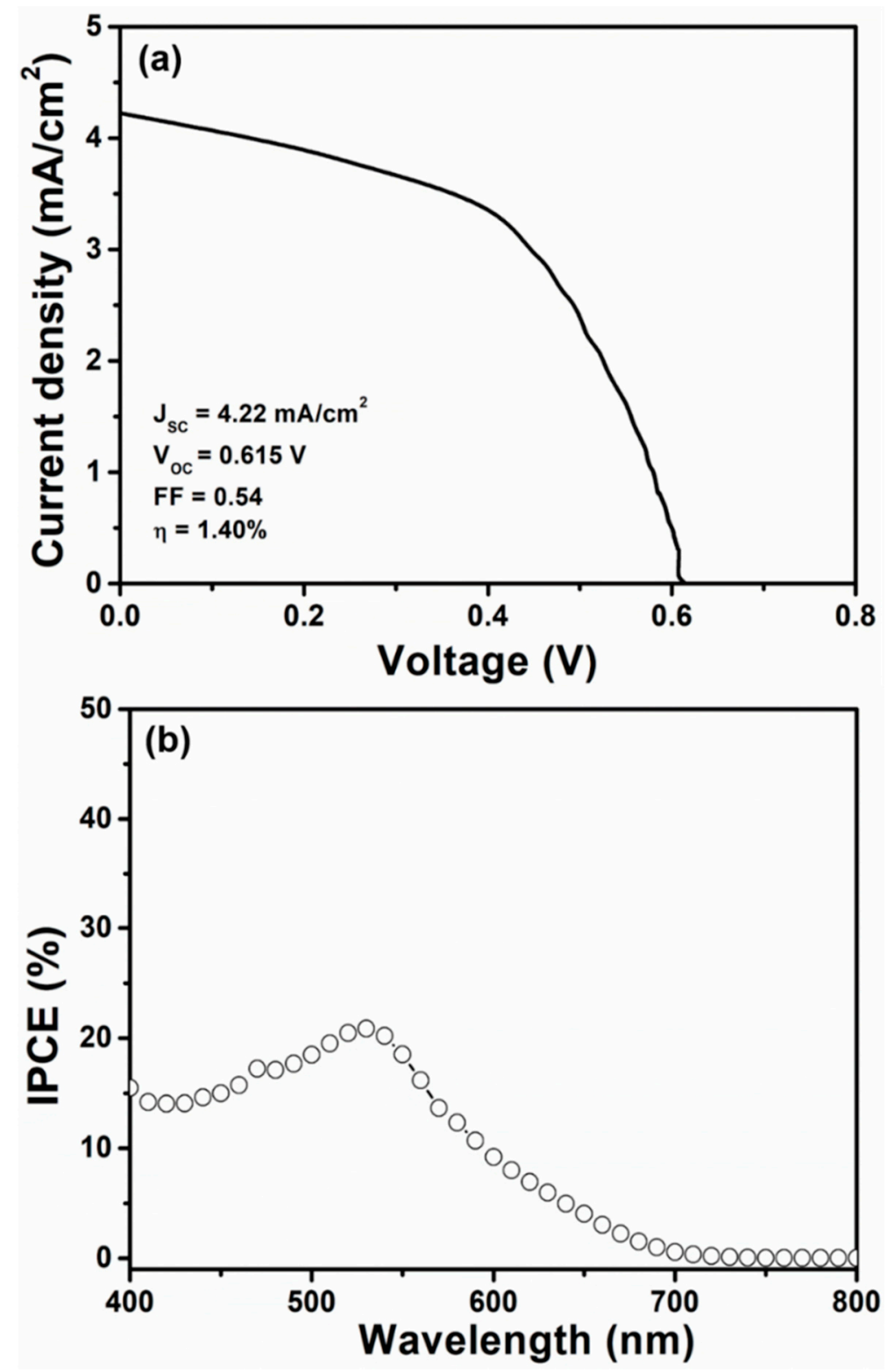

Figure 6. Typical (a) current density-voltage $(J-V)$ characteristics and (b) incident photon-to-current conversion efficiency (IPCE) curve of manufactured dye-sensitized solar cells (DSSCs) with flower-shaped $\mathrm{ZnO}$ nanostructures based photoanode.

The low efficiency and JSC in manufactured DSSC with flower-shaped ZnO nanostructures based photoanode are attributed to its nonuniform distribution of flowers and low specific surface area (Surface area $=8.351 \mathrm{~m}^{2} / \mathrm{g}$ ), resulting in moderate amount of dye absorption via the flower-shaped $\mathrm{ZnO}$ nanostructure based photoanode. The yielded photovoltaic parameters of manufactured DSSC are better than those of similarly DSSCs fabricated with ZnO-based photoanode [47-52]. Moreover, the low $\mathrm{JSC}_{\mathrm{SC}}$ of manufactured DSSC was affiliated to the low surface area and low efficiency of light harvesting. In order to elucidate the light harvesting and photocurrent, an incident photon to current efficiency (IPCE) analysis of the manufactured DSSC with synthesized flower-shaped $\mathrm{ZnO}$ nanostructures based photoanode was measured as a function of wavelength. As we know, the estimation of IPCE is from the efficiencies of the processes which evaluate the solar energy to electrical conversion in DSSCs by using the below equation.

$$
\operatorname{IPCE}(\%)=\eta_{\operatorname{lh}}(\lambda) \eta_{i n j}(\lambda) \eta \operatorname{col}(\lambda)
$$


where $\eta_{\mathrm{lh}}(\lambda)$ is the light-harvesting efficiency, $\eta_{\text {inj }}(\lambda)$ is the electron injection efficiency from the sensitizer into the semiconductor oxide layer, and $\eta \operatorname{col}(\lambda)$ is the electron collection efficiency. Figure $6 \mathrm{~b}$ shows the IPCE curve of the manufactured DSSC with the synthesized flower-shaped $\mathrm{ZnO}$ nanostructure-based photoanode using the range of a wavelength range from 400 to $800 \mathrm{~nm}$. The maximum IPCE of $\sim 21 \%$ at $530 \mathrm{~nm}$ for the manufactured DSSC is attained, and also estimates the integrated JSC value of $\sim 4.67 \mathrm{~mA} / \mathrm{cm}^{2}$ from the obtained IPCE result. It is visible that the integrated JSC value is in well-aligned with the JSC value extracted from the J-V curve. The low IPCE value is also associated to the poor light harvesting efficiency in dye absorbed flower-shaped $\mathrm{ZnO}$ nanostructures based photoanode. Further, the flower-shaped $\mathrm{ZnO}$ nanostructures are assumed to have a poor surface for dye absorption, contributing to the high recombination of electrons and relatively low injection rate of electrons. These factors might have restricted to achieve high performance and photocurrent density in DSSC using flower-shaped ZnO nanostructures based photoanode. Table 1 exhibits the photovoltaic performance of variety of fabricated DSSCs based on the utilization of different $\mathrm{ZnO}$ nanostructures as photoanodes [47-59].

Table 1. Photovoltaic performance of fabricated DSSCs based on different ZnO nanostructurebased photoanodes.

\begin{tabular}{|c|c|c|c|c|c|c|c|}
\hline \multirow{2}{*}{$\begin{array}{l}\text { Morphologies of } \\
\text { ZnO Nanostructures }\end{array}$} & \multirow{2}{*}{ Substrate } & \multirow{2}{*}{ Dye } & \multicolumn{4}{|c|}{ Photovoltaic Performances } & \multirow{2}{*}{ Ref. } \\
\hline & & & $J_{S C}\left(\mathrm{~mA} / \mathrm{cm}^{2}\right)$ & $V_{O C}(\mathbf{V})$ & $F F$ & $\eta(\%)$ & \\
\hline Nanoparticles & FTO & N719 & 5.4 & 0.58 & 0.35 & 1.1 & 47 \\
\hline Tripods & FTO & N719 & 2.80 & 0.55 & 0.54 & 0.88 & 48 \\
\hline Bush-like morphology & FTO & N719 & 3.46 & 0.69 & 0.35 & 0.82 & 49 \\
\hline Nanorods & FTO & N3 & 1.37 & 0.845 & 0.69 & 0.80 & 50 \\
\hline Aligned nanorods & FTO & N719 & 2.08 & 0.736 & 0.43 & 0.66 & 51 \\
\hline $\begin{array}{l}\text { Paddle wheel like } \\
\text { structured } \mathrm{ZnO} \\
\text { nanorod }\end{array}$ & FTO & - & 2.82 & 0.70 & 0.65 & 1.3 & 52 \\
\hline $\mathrm{ZnO}$ nanorods & FTO & N719 & $1.69-2.13$ & - & - & $0.36-0.47$ & 53 \\
\hline $\mathrm{ZnO}$ nanorods & FTO & N719 & 1.52 & 0.361 & 0.37 & 0.21 & 54 \\
\hline $\begin{array}{l}\text { Nanorods + } \\
\text { nanosheets }\end{array}$ & Zn foil & N719 & 3.041 & 0.524 & 0.42 & 0.67 & 55 \\
\hline Nanotubes & ITO & N3 & 4.70 & 0.386 & - & 1.20 & 56 \\
\hline Nanograsses & FTO & N719 & 1.93 & 0.630 & 0.39 & 0.47 & 57 \\
\hline Nanocombs & FTO & N719 & 3.14 & 0.671 & 0.34 & 0.68 & 58 \\
\hline Nanofibers & FTO & N719 & 2.87 & 0.690 & 0.44 & 0.88 & 59 \\
\hline $\begin{array}{l}\text { ZnO nanoflowers } \\
\text { directly grown } \\
\text { on FTO }\end{array}$ & FTO & N719 & 4.22 & 0.615 & 0.54 & 1.40 & This work \\
\hline
\end{tabular}

Electrochemical impedance spectroscopy (EIS) for DSSCs with flower-shaped ZnO nanostructures has been performed to explain the charge transport and recombination mechanisms. Figure 7 illustrates the typical Nyquist plot along with equivalent circuit for the fabricated DSSC with flower-shaped $\mathrm{ZnO}$ nanostructure-based photoanode. Generally, the Nyquist plot comprises of three semicircles with respect to frequency, which are associated with charge transfer within the electrolyte $\left(R_{S}\right)$, charge transfer at electrolyte/counter electrode interface $\left(\mathrm{R}_{\mathrm{CE}}\right)$, and electron transfer at the electrolyte/semiconductor oxide interface $\left(R_{\mathrm{CT}}\right)$ [60], as shown Figure 7. Fabricated DSSC presents the large $R_{\mathrm{CT}}$ of $142 \Omega$ and large $R_{S}$ of $73.5 \Omega$ (as estimated from Figure 7), suggesting the lesser charge transfer at the interface of dye-loaded $\mathrm{ZnO}$ and electrolyte layer. In this work, $\mathrm{R}_{\mathrm{CT}}$ and $\mathrm{R}_{\mathrm{S}}$ values are higher than that of DSSCs fabricated based on $\mathrm{ZnO}$ nanoparticles (low $\mathrm{R}_{\mathrm{S}}$ and low $\mathrm{R}_{\mathrm{CT}}$ ), which clearly indicates weak charge transportation at $\mathrm{ZnO} /$ electrolyte interface [61]. It is believed that the high $\mathrm{R}_{\mathrm{CT}}$ and $\mathrm{R}_{\mathrm{S}}$ values obtained by DSSCs with flower-shaped $\mathrm{ZnO}$ nanostructure-based photoanode clearly explains the unfavorable electron transport, thus it probably leads to fast electron recombination rate. This result is also consistent with low photovoltaic parameters for DSSCs with flower-shaped ZnO nanostructure-based photoanode. 


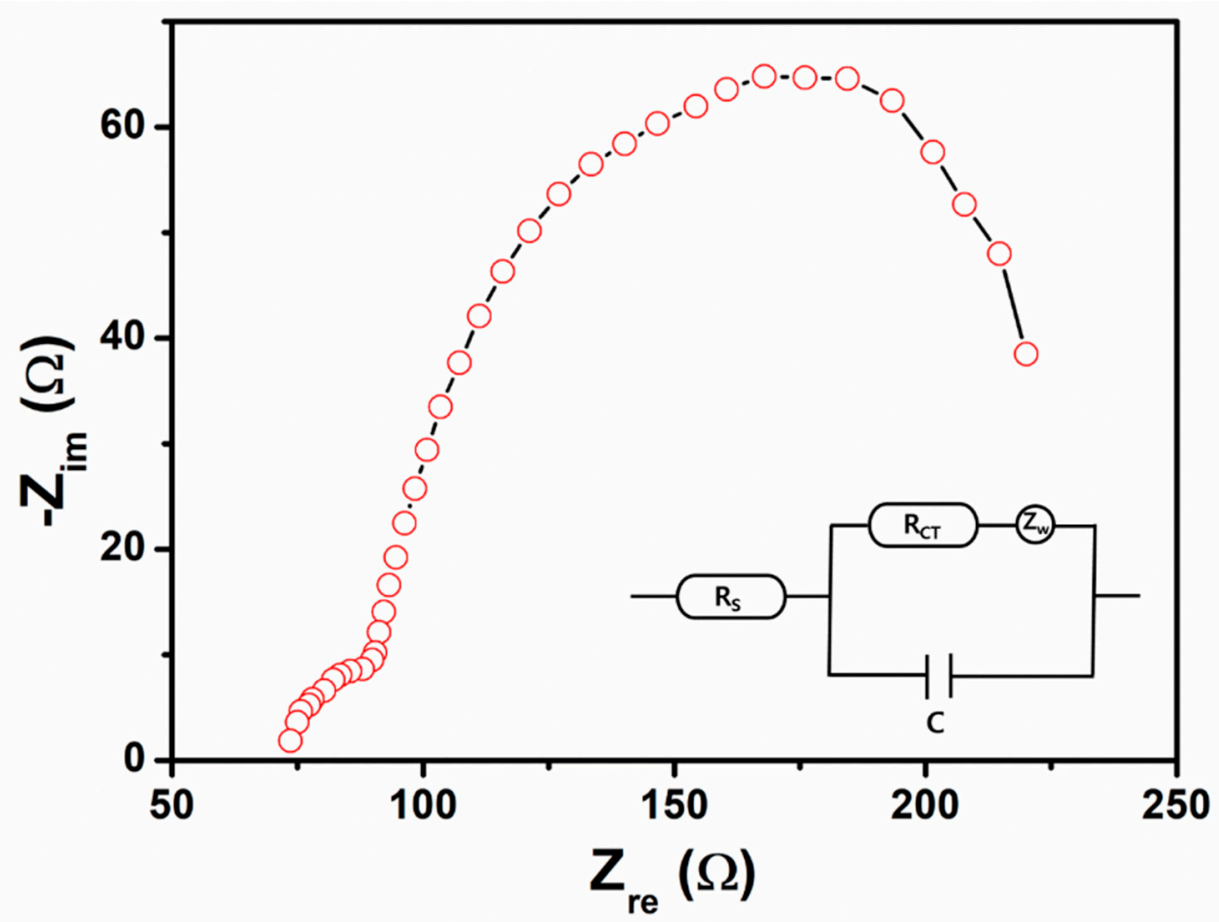

Figure 7. Nyquist plot of fabricated DSSC with flower-shaped ZnO nanostructure-based photoanode and inset shows equivalent circuit of fabricated device.

\section{Conclusions}

In summary, using a simple solution process at low temperature, the flower-shaped $\mathrm{ZnO}$ nanostructures with high crystallinity were directly synthesized on FTO substrate and successfully applied as photoanodes for the manufacturing of DSSC. It was found that the petals in flower morphology were comprised of aggregated small rods with high aspect ratio. XPS studies were confirmed that highly pure $\mathrm{ZnO}$ made up of $\mathrm{Zn}^{2+}$ and $\mathrm{O}^{2-}$ states. The optical and structural characterizations were deduced the excellent crystal quality with lesser defect in the synthesized flower-shaped $\mathrm{ZnO}$ nanostructures. As a photoanode, the manufactured DSSC recorded reasonable overall conversion efficiency of $\sim 1.40 \%$ with good JSC and $\mathrm{V}_{\mathrm{OC}}$. From IPCE curve, the integrated JSC of $\sim 4.67 \mathrm{~mA} / \mathrm{cm}^{2}$ is similar to JSC value extracted from J-V curve. It is confirmed from this study that the reported route of synthesis is an easy method for preparing high quality $\mathrm{ZnO}$ crystal with flower-like morphology, which has excellent prospects in photoelectrochemical applications.

Author Contributions: A.U., M.S.A., T.A., A.A.I. and S.B. conceived and designed the experiments; A.U., M.S.A., T.A., A.A.I., Y.M. and Q.I.R. performed the experiments and characterized the samples, A.U., M.S.A., T.A., A.A.I., M.S., A.Y.M. and Q.I.R. analyzed the data contributed reagents/materials/analysis tools and wrote the paper.

Funding: This work was funded by the Deanship of Scientific Research (DSR), Najran University, Najran, under grant no. NU/ESCI/16/016.

Acknowledgments: The authors, therefore, greatly acknowledge with thanks DSR, Najran University for technical and financial support.

Conflicts of Interest: The authors declare no conflicts of interest.

\section{References}

1. $\mathrm{Xu}, \mathrm{F}$; Sun, L. Solution-derived $\mathrm{ZnO}$ nanostructures for photoanodes of dye-sensitized solar cells. Energy Environ. Sci. 2011, 4, 818. [CrossRef]

2. Zhang, T.; Yang, W.; Yang, Q.; Yang, P.; Sun, W. Cost-Efficient Chemical Bath Synthesized Alloy Catalysts $\mathrm{PtM}_{0.05}(\mathrm{M}=\mathrm{Fe}, \mathrm{Co}, \mathrm{Ni})$ Acting as Counter Electrodes for CdS Quantum Dot Sensitized Solar Cell. Sci. Adv. Mater. 2018, 10, 1489-1497. [CrossRef] 
3. Heo, J.H.; Lee, M.H.; Song, D.H.; Aung, N.M.S.; Lee, J.J.; Song, C.E.; Hong, K.H.; Im, S.H. Highly Stable All-Inorganic Pb-Free Perovskite Solar Cells. J. Nanoelectron. Optoelectron. 2018, 13, 1764-1768. [CrossRef]

4. Ni, S.; Guo, F.; Wang, D.; Jiao, S.; Wang, J.; Zhang, Y.; Wang, B.; Feng, P.; Zhao, L. Modification of TiO 2 Nanowire Arrays with Sn Doping as Photoanode for Highly Efficient Dye-Sensitized Solar Cells. Crystals 2019, 9, 113. [CrossRef]

5. Patil, V.; Patil, A.; Yoon, S.J.; Choi, J.W. Electrochemical Characterization of Si/Al Multilayer Thin Film Anode Materials for High Energy Lithium Secondary Batteries. Sci. Adv. Mater. 2018, 10, 507-512. [CrossRef]

6. Gleiter, H. Nanostructured materials: Basic concepts and microstructure. Acta Mater. 2018, 48, 1-29. [CrossRef]

7. Umar, A.; Singh, P.; Al-Ghamdi, A.A.; Al-Heniti, S. Direct Growth of ZnO Nanosheets on FTO Substrate for Dye-Sensitized Solar Cells Applications. J. Nanosci. Nanotech. 2010, 10, 6666-6671. [CrossRef]

8. Cho, D.H.; Lee, W.J.; Wi, J.H.; Yu, H.J.; Han, W.S.; Chung, Y.D. Engineering of Sodium Supply into $\mathrm{Cu}(\mathrm{In}, \mathrm{Ga}) \mathrm{Se}_{2}$ Thin-Film Solar Cells. J. Nanoelectron. Optoelectron. 2018, 13, 1753-1757. [CrossRef]

9. Cao, V.M.H.; Hwang, S.H.; Lin, J.; Lee, S.H.; Kim, S.; Lee, J. Effects of Photosintering on Properties of Cadmium Sulfide Thin Films for Highly Efficient $\mathrm{Cu}(\mathrm{In}, \mathrm{Ga})(\mathrm{Se}, \mathrm{S})_{2}$ Solar Cells. Sci. Adv. Mater. 2018, 10, 1133-1139. [CrossRef]

10. Yella, A.; Lee, H.W.; Tsao, H.N.; Yi, C.; Chandiran, A.K.; Nazeeruddin, M.K.; Diau, E.W.G.; Yeh, C.Y.; Zakeeruddin, S.M.; Gratzel, M. Porphyrin-sensitized solar cells with cobalt (II/III)-based redox electrolyte exceed 12 percent efficiency. Science 2011, 334, 629-634. [CrossRef]

11. Akhtar, M.S.; Ameen, S.; Jung, I.S.; Choi, J. Facile Synthesis of Hexagonal ZnO Nanorods for Dye-Sensitized Solar Cell Application. J. Nanoelectron. Optoelectron. 2018, 13, 1912-1916. [CrossRef]

12. Yu, W.C.; Sabastian, N.; Chang, W.C.; Tsia, C.Y.; Lin, C.M. Electrochemical Deposition of ZnO Porous Nanoplate Network for Dye-Sensitized Solar Cells. J. Nanosci. Nanotechnol. 2018, 18, 56-61. [CrossRef] [PubMed]

13. Al-Hajry, A.; Umar, A.; Hahn, Y.B.; Kim, D.H. Growth, properties and dye-sensitized solar cells applications of $\mathrm{ZnO}$ nanorods grown by low-temperature solution process. Superlattices Microstruct. 2009, 45, 529-534. [CrossRef]

14. Jang, J.S.; Kim, J.; Suryawanshi, M.P.; Lokhande, A.C.; Shin, H.H.; Lee, D.S.; Kim, J.H. Effect of Radio Frequency Power on the Properties of Al-Doped ZnO (AZO) Thin Films and Their Application to $\mathrm{Cu}_{2} \mathrm{ZnSn}(\mathrm{S}, \mathrm{Se})_{4}$ Thin-Film Solar Cells. J. Nanoelectron. Optoelectron. 2018, 13, 1689-1694. [CrossRef]

15. Vittala, R.; Ho, K.C. Zinc oxide based dye-sensitized solar cells: A review. Renew. Sustain. Energy Rev. 2017, 70, 920-935. [CrossRef]

16. Sacco, A.; Lamberti, A.; Gazia, R.; Bianco, S.; Manfredi, D.; Shahzad, N.; Cappelluti, F.; Mac, S.; Tresso, E. High efficiency dye-sensitized solar cells exploiting spongelike $\mathrm{ZnO}$ nanostructures. Phys. Chem. Chem. Phys. 2012, 14, 16203-16208. [CrossRef] [PubMed]

17. Cheng, C.; Shi, Y.; Zhu, C.; Li, W.; Wang, L.; Fung, K.K.; Wang, N. ZnO hierarchical structures for efficient quasi-solid dye-sensitized solar cells. Phys. Chem. Chem. Phys. 2011, 13, 10631-10634. [CrossRef]

18. Pugliese, D.; Bella, F.; Cauda, V.; Lamberti, A.; Sacco, A.; Tresso, E.; Bianco, S. A chemometric approach for the sensitization procedure of $\mathrm{ZnO}$ flowerlike microstructures for dye-sensitized solar cells. ACS Appl. Mater. Interfaces 2013, 5, 11288-11295. [CrossRef]

19. Parks, G.A. The isoelectric points of solid oxides, solid hydroxides, and aqueous hydroxo complex systems. Chem. Rev. 1965, 65, 177-198. [CrossRef]

20. Chandrakala, V.; Steffy, J.A.J.; Bachan, N.; Jeyarani, W.J.; Tenkyong, T.; Shyla, J.M. A Comparative Investigation of Dye-Sensitized Titanium Dioxide $\left(\mathrm{TiO}_{2}\right)$ Nanorods Grown on Indium Tin Oxide (ITO) Substrates by Direct and Seed-Mediated Hydrothermal Methods. Acta Metallurgica Sinica Engl. Lett. 2016, 29, 457-463. [CrossRef]

21. Meyer, B.K.; Alves, H.; Hofmann, D.M.; Kriegseis, W.; Forster, D.; Bertram, F.; Christen, J.; Hoffmann, A.; Straburg, M.; Dworzak, M.; et al. Bound exciton and donor-acceptor pair recombinations in ZnO. Phys. Status Solidi Basic Res. 2004, 241, 231-260. [CrossRef]

22. Yang, J.; Yi, W.; Zhang, L.; Li, T.; Chao, Z.; Fan, J. Facile Fabrication of ZnO Nanomaterials and Their Photocatalytic Activity Study. Sci. Adv. Mater. 2018, 10, 1721-1728. [CrossRef]

23. Talib, R.A.; Ahmed, N.M.; Mohammad, S.M.; Abdullah, M.J.; Bououdina, M. ZnO Nanorods/Polyaniline Heterojunction onto $\mathrm{SiO}_{2}$ for Photosensor. J. Nanoelectron. Optoelectron. 2018, 13, 1034-1040. [CrossRef] 
24. Hassan, N.K.; Hashim, M.R.; Allam, N.K. ZnO nano-tetrapod photoanodes for enhanced solar-driven water splitting. Chem. Phys. Lett. 2012, 549, 62-66. [CrossRef]

25. Nam, G.; Leem, J.Y. Cadmium Chloride-Assisted ZnO Nanorod Regrowth for Enhanced Photoluminescence and Ultraviolet Sensing Properties. Sci. Adv. Mater. 2018, 10, 397-400. [CrossRef]

26. Tan, W.K.; Muto, H.; Ito, T.; Kawamura, G.; Lockman, Z.; Matsuda, A. Facile Fabrication of Plasmonic Enhanced Noble-Metal-Decorated ZnO Nanowire Arrays for Dye-Sensitized Solar Cells. J. Nanosci. Nanotechnol. 2020, 20, 359-366.

27. Wang, Z.H.; Yang, C.C.; Yu, H.C.; Peng, Y.M.; Su, Y.K. Electron Emission Enhanced Properties of Gold Nanoparticle-Decorated ZnO Nanosheets Grown at Room Temperature. Sci. Adv. Mater. 2018, 10, 1675-1679. [CrossRef]

28. Özgür, Ü.; Alivov, Y.I.; Liu, C.; Teke, A.; Reshchikov, M.A.; Doğan, S.; Avrutin, V.; Cho, S.J.; Morkoc, H. A comprehensive review of $\mathrm{ZnO}$ materials and devices. J. Appl. Phys. 2005, 98, 1-103. [CrossRef]

29. Kim, E.B.; Lee, J.E.; Akhtar, M.S.; Ameen, S.; Fijahi, L.; Seo, H.K.; Shin, H.S. Electrical Sensor Based on Hollow ZnO Spheres for Hydrazine Detection. J. Nanoelectron. Optoelectron. 2018, 13, 1769-1776. [CrossRef]

30. Ameen, S.; Akhtar, M.S.; Kim, Y.S.; Yang, O.-B.; Shin, H.-S. Influence of seed layer treatment on low temperature grown $\mathrm{ZnO}$ nanotubes: Performances in dye sensitized solar cells. Electrochim. Acta 2011, 56, 1111-1116. [CrossRef]

31. Park, H.; Alhammadi, S.; Bouras, K.; Schmerber, G.; Ferblantier, G.; Dinia, A.; Slaoui, A.; Jeon, C.W.; Park, C.; Kim, W.K. Nd-Doped $\mathrm{SnO}_{2}$ and $\mathrm{ZnO}$ for Application in $\mathrm{Cu}(\mathrm{InGa}) \mathrm{Se}_{2}$ Solar Cells. Sci. Adv. Mater. 2017, 9, 2114-2120. [CrossRef]

32. Akhtar, M.S.; Cheralathan, K.K.; Chun, J.M.; Yang, O.B. Composite electrolyte of heteropolyacid (HPA) and polyethylene oxide (PEO) for solid-state dye-sensitized solar cell. Electrochim. Acta 2008, 53, 6623. [CrossRef]

33. Galoppini, E.; Rochford, J.; Chen, H.; Saraf, G.; Lu, Y.; Hagfeldt, A.; Boschloo, G. Fast Electron Transport in Metal Organic Vapor Deposition Grown Dye-sensitized ZnO Nanorod Solar Cells. J. Phys. Chem. B 2006, 110, 16159. [CrossRef] [PubMed]

34. Chen, H.M.; Chen, C.K.; Liu, R.-S.; Zhang, L.; Zhang, J.; Wilkinson, D.P. Nano-architecture and material designs for water splitting photoelectrodes. Chem. Soc. Rev. 2012, 41, 5654-5671. [CrossRef] [PubMed]

35. Kaur, M.; Umar, A.; Mehta, S.K.; Singh, S.; Kansal, S.K.; Fouad, H.; Alothman, O.Y. Rapid solar-light driven photocatalytic degradation of methylene blue using $\mathrm{MoS}_{2}-\mathrm{ZnO}$ heterostructure nanorods photocatalyst. Materials 2018, 11, 2254.

36. Kumar, R.; Umar, A.; Rana, D.S.; Sharma, P.; Chauhan, M.S.; Chauhan, S. Fe-doped ZnO nanoellipsoids for enhanced photocatalytic and highly sensitive and selective picric acid sensor. Mater. Res. Bull. 2018, 102, 282-288. [CrossRef]

37. Marimuthu, T.; Anandhan, N. Effect of polyvinyl alcohol on electrochemically deposited ZnO thin films for DSSC applications. AIP Conf. Proc. 2017, 1832, 080014.

38. Özdal, T.; Taktakoglu, R.; Özdamar, H.; Esen, M.; Takçi, D.K.; Kavak, H. Crystallinity improvement of ZnO nanorods by optimization of low-cost electrodeposition technique. Thin Solid Films 2015, 592 Pt A, 143-149. [CrossRef]

39. Umar, A.; Hahn, Y.B. Ultraviolet-Emitting ZnO Nanostructures on Steel Alloy Substrate: Growth and Properties. Cryst. Growth Des. 2008, 8, 2741-2747. [CrossRef]

40. Umar, A.; Kim, S.H.; Karunagaran, B.; Suh, E.-K.; Hahn, Y.B. Growth and optical properties of aligned hexagonal $\mathrm{ZnO}$ nanoprisms on silicon substrate by non-catalytic thermal evaporation. Inorg. Chem. 2008, 47, 4088-4094. [CrossRef]

41. Umar, A.; Kim, S.H.; Suh, E.-K.; Hahn, Y.B. Ultraviolet-emitting javelin-like ZnO nanorods by thermal evaporation: Growth mechanism, structural and optical properties. Chem. Phys. Lett. 2007, 440, 110-115. [CrossRef]

42. Umar, A.; Ribeiro, C.; Al-Hajry, A.; Masuda, Y.; Hahn, Y.B. Growth of highly c-axis oriented ZnO nanorods on ZnO/Glass substrate: Growth mechanism, Structural and Optical properties. J. Phys. Chem. C 2009, 113, 14715-14720. [CrossRef]

43. Madlol, R.A.A. Structural and optical properties of $\mathrm{ZnO}$ nanotube synthesis via novel method. Results Phys. 2017, 7, 1498-1503. [CrossRef]

44. Yang, J.; Wang, Y.; Kong, J.; Jia, H.; Wang, Z. Synthesis of ZnO nanosheets via electrodeposition method and their optical properties, growth mechanism. Opt. Mater. 2015, 46, 179-185. [CrossRef] 
45. Ameen, S.; Akhtar, M.S.; Shin, H.-S. Speedy photocatalytic degradation of bromophenol dye over ZnO nanoflowers. Mater. Lett. 2017, 209, 150-154. [CrossRef]

46. Marimuthu, T.; Anandhan, N.; Thangamuthu, R.; Surya, S. Facile growth of ZnO nanowire arrays and nanoneedle arrays with flower structure on $\mathrm{ZnO}-\mathrm{TiO}_{2}$ seed layer for DSSC applications. J. Alloys Compd. 2017, 693, 1011-1019. [CrossRef]

47. Patwari, J.; Shyamal, S.; Khan, T.; Ghadi, H.; Bhattacharya, S.; Chakrabarti, S.; Pal, S.K. Inversion of activity in DSSC for $\mathrm{TiO}_{2}$ and $\mathrm{ZnO}$ photo-anodes depending on the choice of sensitizer and carrier dynamics. J. Luminescence 2019, 207, 169-176. [CrossRef]

48. Bahadur, L.; Kushwaha, S. Structural and optical properties of tripod-like ZnO thin film and its application in dye- sensitized solar cell. J. Solid State Electron. 2013, 17, 2001-2008. [CrossRef]

49. Qin, Z.; Huang, Y.; Qi, J.; Li, H.; Su, J.; Zhang, Z. Facile synthesis and photoelectrochemical performance of the bush-like ZnO nanosheets film. Solid State Sci. 2012, 14, 155-158. [CrossRef]

50. Rajan, A.K.; Cindrella, L. Ameliorating the photovoltaic conversion efficiency of ZnO nanorod based dye-sensitized solar cells by strontium doping. Superlatt. Microstruc. 2019, 128, 14-22. [CrossRef]

51. Dou, Y.; Wu, F.; Mao, C.; Fang, L.; Guo, S.; Zhou, M. Enhanced photovoltaic performance of ZnO nanorod-based dye-sensitized solar cells by using Ga doped ZnO seed layer. J. Alloys Comp. 2015, 633, 408-414. [CrossRef]

52. Senthil, T.S.; Muthukumarasamy, N.; Kang, M. Applications of highly ordered paddle wheel like structured ZnO nanorods in dye sensitized solar cells. Mater. Lett. 2013, 102-103, 26-29. [CrossRef]

53. Cai, F.; Wang, J.; Yuan, Z.; Duan, Y. Magnetic-field effect on dye-sensitized ZnO nanorods-based solar cells. J. Power Sour. 2012, 216, 269-272. [CrossRef]

54. Gonzalez-Valls, I.; Lira-Cantu, M. Effect of testing conditions on the photovoltaic performance of ZnO-based dye sensitized solar cells. Phys. Procedia 2010, 8, 28-32. [CrossRef]

55. Zhu, S.; Shan, L.; Tian, X.; Zheng, X.; Sun, D.; Liu, X.; Wang, L.; Zhou, Z. Hydrothermal synthesis of oriented $\mathrm{ZnO}$ nanorod-nanosheets hierarchical architecture on zinc foil as flexible photoanodes for dye-sensitized solar cells. Ceram. Int. 2014, 40, 11663-11670. [CrossRef]

56. Liu, Z.; Liu, C.; Ya, J.; Lei, E. Controlled synthesis of $\mathrm{ZnO}$ and $\mathrm{TiO} 2$ nanotubes by chemical method and their application in dye-sensitized solar cells. Renew. Energy 2011, 36, 1177-1181. [CrossRef]

57. Zhu, S.; Chen, X.; Zuo, F.; Jiang, M.; Zhou, Z.; Hui, D. Controllable synthesis of ZnO nanograss with different morphologies and enhanced performance in dye-sensitized solar cells. J. Solid State Chem. 2013, 197, 69-74. [CrossRef]

58. Umar, A. Growth of comb-like ZnO nanostructures for Dye-sensitized solar cells applications. Nanoscale Res. Lett. 2009, 4, 1004-1008. [CrossRef]

59. Li, S.; Zhang, X.; Jiao, X.; Lin, H. One-step large-scale synthesis of porous ZnO nanofibers and their application in dye-sensitized solar cells. Mater. Lett. 2011, 65, 2975-2978. [CrossRef]

60. Wang, Z.S.; Kawauchi, H.; Kashima, T.; Arakawa, H. Significant influence of $\mathrm{TiO}_{2}$ photoelectrode morphology on the energy conversion efficiency of N719 dye-sensitized solar cell. Coord. Chem. Rev. 2004, 248, 1381-1389. [CrossRef]

61. Golsheikh, A.M.; Kamali, K.Z.; Huang, N.M.; Zak, A.K. Effect of calcination temperature on performance of $\mathrm{ZnO}$ nanoparticles for dye-sensitized solar cells. Powder Technol. 2018, 329, 282-287. [CrossRef]

(C) 2019 by the authors. Licensee MDPI, Basel, Switzerland. This article is an open access article distributed under the terms and conditions of the Creative Commons Attribution (CC BY) license (http://creativecommons.org/licenses/by/4.0/). 